\title{
American Legal Realism in Dispute Resolution. Alternative Dispute Resolution as a "Realist" Project ${ }^{\mathrm{I}}$ \\ Realismo estadounidense en la resolución de conflictos. \\ La resolución alternativa de conflictos como un proyecto "realista"
}

\author{
Carlo Vittorio Giabardo ${ }^{2}$ \\ University of Girona, Càtedra de Cultura Juridica, España
}

\begin{abstract}
American Legal Realism is alive and well. As a normative (and not only descriptive) theory, it has shaped the legal world we are living in and has influenced current legal practices at a global level. This article looks at the influence Realists' ideas (and specifically Charles Edward Clark's ones) have had 'unconsciously' over the phenomenon of the privatisation of civil justice and the Alternative Dispute Resolution revolution. It is suggested that many key concepts of Pragmatism and American Legal Realism form part of today's repertoire of Alternative Dispute Resolution supporters and that the privatisation of civil justice is to be understood as an "unintended" Realist project, in the sense that it is inspired by, and reflects, a Realist view about law, conflict-resolution and justice without openly recognizing it.
\end{abstract}

\section{Keywords}

Philosophy of Law, American Legal Realism, Pragmatism, Theory of Adjudication, Alternative Dispute Resolution, Mediation.

\section{Resumen}

El realismo jurídico estadounidense está vivo y robusto. Como teoría normativa (y no solo descriptiva), ha dado forma al mundo legal en el que estamos viviendo y ha influido en las prácticas legales actuales a nivel global. Este artículo analiza la influencia que las ideas de autores realistas (específicamente las de Charles Edward Clark) han tenido "inconscientemente" sobre el fenómeno de la privatización de la justicia civil y sobre la revolución que implicó la resolución alternativa de conflictos. El texto sugiere que muchos conceptos clave del pragmatismo y del realismo jurídico estadounidense forman parte del repertorio actual de partidarios de la resolución alternativa de conflictos. Asimismo, que la privatización de la justicia civil debe entenderse como un proyecto "no intencionado" del realismo, pues está inspirado por y refleja una visión realista del derecho, la resolución de conflictos y la justicia, aunque sin reconocerlo abiertamente.

\footnotetext{
${ }^{1}$ This paper extends and develops some reflections presented at the World Congress of the International Association for the Philosophy of Law and Social Philosophy (I.V.R.) hosted by the University of Lucerne (Switzerland), July 2019, Special Workshop "On the Philosophical and Sociological Foundations of North American Legal Realism". I am especially grateful to the organizers, Dr. Marco Segatti (University of Chicago Law School) and Dr. Luca Malagoli (Tarello Institute for Legal Philosophy, University of Genova.).

2 "Juan de la Cierva" Postdoctoral Research Fellow in Law, University of Girona (Spain), Càtedra de Cultura Juridica. PhD in Law, University of Turin (Italy). E-mail: carlovittorio.giabardo@udg.edu ORCID: https:/orcid.org/0000-0002-7993-6762
} 


\section{Palabras clave}

Filosofía del derecho, Realismo jurídico estadounidense, Pragmatismo, Teoría de la adjudicación, Resolución alternativa de disputas, Mediación.

\section{The "Normative Dimension" of American Legal Realism}

It is a commonly-held wisdom that American Legal Realism (hereinafter, ALR) has been an influential descriptive theory about how law truly works (i.e., how law is), but lacked any coherent normative ideas for how legal institutions are expected to function (i.e., how law should be). Its proponents - it is said- were so concerned in criticizing formalist accounts of law, and substituting them with more useful explanations about the actual process of decisionmaking by judges (considering, for example, the role their personal preferences or their individual traits play or, more generally, their responsiveness to extra-legal factors, and so on) that they left apart the construction of a purposeful theory that aspires to provide any kind of guidance for law or decision-makers. ALR was an intellectual movement that, in essence, aimed explicitly to destruct previous beliefs and overturn accepted attitudes, prevailing approaches, methodologies, explanations, ways of teaching law, myths, and the like, but never aimed to provide the "building blocks" for the future directions of law. In short — so the narrative goes while ALR provided a much-needful part destruens, it avoided almost completely to lay down a solid part construens ${ }^{3}$. After having devastatingly critiqued what we have been knowing (or, better said, believing) about law, the role of legal rules, and the activity of judges, they have left us with nothing much in hands in order to solve social problems, improve common good and provide guidance in reforming legal institutions. If law is nothing, if law means nothing, then it would be contradictory to believe to change things through law.

This picture is far from being accurate. In fact, ALR has had an enormous impact on subsequent legal reforms and on the ways we judge and implement new legal institutions and practices. Some of its exponents showed, in their thoughts, a remarkably neat and distinctive "normative dimension" that is seldom taken into consideration in current discussions. Basically, this normative dimension is recognizable on two grounds: one is historical and, so to say, "biographical", and the other one looks at the present state of affairs.

First of all, if Realists did not believe in the power, or in the capacity, of the law to purport social-legal change at all, it would be puzzling to explain why the writings of so many of them possessed a clear reformistic outlook, and why much of their work undoubtedly aimed to reform certain bodies of law in order that they reflected their values (Leiter, 2015). During the heyday of ALR, many of its most famous members got involved in major reform projects of American laws. Jerome Frank (the most radical "rule-sceptic" of the movement) contributed significantly to the New Deal reforms ${ }^{4}$, and so did Felix S. Cohen and William Douglas (Mitchell, 2007). Famously, Karl Llewellyn served as the "Chief Reporter" in the drafting of the Uniform Commercial Code from 1942 until his death and influenced deeply the underlying "jurisprudence" 5 . Charles Edward Clark —a leading figure of ALR (but whose

\footnotetext{
${ }^{3}$ See, e.g., Gilmore (1961, p. 1037): "Realism appears to have been a high-level jurisprudential or philosophical movement [...] which offered a critical analysis, of a destructive or negative character, of certain then widely accepted theories of law". Compare also Duxbury (1995, p. 158): "Realism evolved as a broad critique of the formalist assumptions [...] Beyond this critique, however, there remained little but a marked absence of vision"; Mensch (2010, p. 25-26), according to which Realism "was so corrosive that many of the most influential realists evaded the full implications of their own criticism".

${ }^{4}$ On Jerome Frank, see Glennon (1985) and, more recently, Curtis (2015).

${ }^{5}$ On the contribution of Karl Llewellyn to the UCC, see Maggs (2000); Kamp (1995), Danzig (1975).
} 
contribution has inexplicably received little attention in modern scholarship) — is commonly recognized as one of founding fathers of the reform of the Federal Rules of Civil Procedure (that came into force in 1938), in which he translated into practice his ideas on the judicial function and adjudication, and he has also later served as an advisor for the Restatement of the Law of Property ${ }^{6}$. More recently, Charles Alan Wright, "an unabashed Legal Realist", as so defined by Brian Leiter (2015, p. 1976), has even been the President of the American Law Institute. Because of this, it would be quite paradoxical to maintain that Realists in their entirety did not support any normative theories of law and decision making or that they did not endorse any ideas on what is good, and what is not, legally speaking (Kalman, 1986, p. 42; Kalman, 1997).

Secondly, it cannot be denied that ALR has shaped normatively, de facto, the legal world we all live in. Indeed, the legacy of ALR is to be found, for example, in the subsequent American scholarship and legal theory, which has contributed to a new reading of reality, such as, e.g., the Critical Legal Studies in the late '70s (Tushnet, 1991), and then the following jurisprudential movements, the Critical Race Theory ${ }^{7}$, Feminist Jurisprudence, the Law and Gender, and many others, or, more recently, the "New Legal Realism" (Milesm and Sunstein, 2008). Also, it has impacted legal education and teaching and the concrete ways the legal world we inhabit has been designed and construed more generally. Realists' ideas, while unmasking previous assumptions on law, have also provided the current categories through which we evaluate and assess — whether consciously or not - our existing institutions, rules, reforms and practices. ALR has tremendously influenced the way most of our legal experiences have been framed, conceptualized, evaluated, and therefore, accepted or rejected in many areas of law: commercial law, contract law, tort law, international law, and civil justice. Realists' thoughts created a new standard for understanding legal practices that has become part of our shared common mentality. Consequently, we often judge today's legal institutions as good or bad, or useful or ineffective, through Realist's eyes - and this is clearly a result that could be characterized in normative terms. This point will be tackled more in details later, when addressing how Realists' ideas have unintentionally, but significantly, shaped one of the most important global tendencies of today's world, namely the Alternative Dispute Resolution (hereinafter: ADR) movement and the privatization of civil justice ${ }^{8}$. But this very argument could be easily made general: we are all living in a "post-realist" world and — as Elizabeth Mensch has correctly remarked (2010, pp. 34-35) — there is "no return to the naïve confidence of the past".

\section{The Pragmatic Foundations of American Legal Realism and its 'Methodological Normativism'}

The question in what sense, and to what extent, Realists endorsed a normative theory of law is a still much-debated one. It is a topic that could be tackled from a variety of perspectives. For current purposes, this part elaborates upon what could be called the "methodological normativity" of ALR, that is a set of opinions on how methods of taking decisions (and, emblematically, adjudication) should be designed and arranged. Since this kind of "normativity" drew on, and is consistent with, the adoption of pragmatism as the philosophical foundation of ALR, a brief account of those key ideas of pragmatism that are relevant for the Realist view of decision-making procedures and — as it will be argued — for a better understanding of today's ADR revolution is, thus, necessary.

\footnotetext{
${ }^{6}$ For a thorough account of the works and ideas of Charles Clark, both as a theorist of ALR and as a reformer, see Marcus (2010).

${ }^{7}$ Openly recognizing the debt with Legal Realism, see Bell (1992).

${ }^{8}$ See infra, paragraph 4 .
} 
As this article argues, there is a continuum in the basic rationale not only between Pragmatism and ALR, but also between Pragmatism and what I identify as the "ADR legal thought" namely, that cluster of beliefs, doctrines and conceptions about law, rules and justice that is shared and embraced by ADR proponents- . The parallelism between these three approaches is striking. In short, Pragmatists adopted the so-called "methodological functionalism", i.e., a problem-solving posture as a method of taking decision, and emphasised the role and the capacity of facts in determining the content of those decisions; therefore, they purported a contextual and plural version of truth. Similarly, both Realists and ADR theorists adopted, and still adopt, a functional view of rules, put an emphasis on the importance of considering the totality of factual circumstances (broadly conceived) as an element for solving conflicts, and thus champion a contextual-dependent and contingent version of justice.

It is well-know that ALR's philosophical foundation is American pragmatism, since its inception: Oliver Wendell Holmes was a founding member of the ironically-titled 'Metaphysical Club' of Pragmatists in Cambridge (Massachusetts), he participated in it, although only initially, and attended some of Charles Pierce's lectures?.

For present purposes and for simplicity's sake, pragmatism will be here considered as a method of reasoning, or a general attitude ${ }^{10}$, that could be summarized as follows: concepts and hypothesis are to be assessed only in the light of their practical consequences - i.e. for their implications for experience in specific situations - ${ }^{11}$. This claim could be labelled as "methodological functionalism". Methodological functionalism is based on the exigence that solving specific problems is the task of knowledge. Concrete problems should be the starting point of every human inquiry, and people should think afresh to solve them. Previous rules and, more generally, traditions should be merely seen as guides, tentative devices we should be ready to willingly change if proven wrong, namely if they lead us to undesirable results. Of course, our capacity to solve problems relies upon the completeness of the information available, namely upon the amount of data we have about the particular experiences, contexts, events at stake. The more we know about the world, the better we would be able to give answers. Therefore, the 'road' that goes from the problem tackled to the desirable solution, i.e., that goes from doubt to belief, should therefore be free from any undue, and empirically unverified, influences. It follows that, if an assertion permits to solve a problem, then that assertion is true. Truth is characterized as usefulness, and "rightness" as "fitness". If, for Pragmatists (and specifically John Dewey and William James), truth is defined only in terms of utility and its validity depends (pragmatically and empirically) upon its success, then truth is contingent, plural $^{12}$.

This is what William James in his classic contribution (1907, p. 30) famously called the "instrumental view of truth", defined as:

any idea that will carry us prosperously from any one part of our experience to any other part, linking things satisfactorily, working securely, simplifying, saving labor; is true for just so much, true in so far forth, true instrumentally. This is the "instrumental" view of truth.

\footnotetext{
${ }^{9}$ On the pragmatic foundations of Legal Realism, see Haack (2018). See also Bix (2008) and Alberstein (2002). On the variety of pragmatist traditions and their impact on law, see Haack (2005).

${ }^{10}$ As Posner (2003, p. 26) pointed out: "pragmatism is more a tradition, attitude, and outlook than a body of doctrine".

${ }^{11}$ Generally, on pragmatism as a philosophical movement, see Legg and Hookway (2019).

${ }^{12}$ However, for important specifications on the "pragmatic conception of truth" see Capps (2019), Haack (1976), and Rorty (1990).
} 
These words have been reported as they are crucial to understand the notion of justice Realists supported, which is very similar, in turn, to the one ADR exponents today argue for. Pluralism of truth for Pragmatists translated into pluralism of justice for Realists and ADR proponents. Truth, for Pragmatists, is what solves a problem. Similarly, justice in Realists' eyes is what solves a legal problem. Rightness, for Pragmatists, is fitness (to a situation). Similarly, justice, for Realists and ADR scholars, is fitness (to a legal controversy). These points will be discussed more at length later on ${ }^{13}$. Suffice here to note that in the pragmatic worldview there is no room for conceptualism, formalism, abstraction, dogmatism, absolutes values, nor for the mechanical operation of antecedently-fixed concepts, ready-made principles, answers, traditions, patterns of thought, and a-priori ways of thinking. The validity of any assertions is always to be assessed on a case by case basis, depending on their capacity to provide good solutions to particular problems of particular contexts, at particular times, and for particular individuals. Overall, according to Pragmatists, a good method of inquiry and a good amount of empirical data is all that we need to progress. If we possess these elements, the outcome will follow almost automatically. To paraphrase a Lon Fuller's statement, Pragmatists' attitude could be summarized like that "If we do things the right way, we are likely to do the right thing" (in Fuller, 1948, p. 204).

This philosophical method had an enormous impact upon Realists and upon their way to conceive decision-making procedures and the notion of justice. Indeed, as a general matter, Realists, likewise Pragmatists, agreed upon the methodological functionalism or "pragmatic instrumentalism" (Summers, 1981) sketched above. ${ }^{14}$ For them, as Karl Llewellyn remarked, rules are only "means to ends" and they hold meaning only "insofar they are means to ends" (Llewellyn, 1934, p. 205). What those "ends" should be, thought, is rarely stated with clarity - hence the accusation of "moral relativism" often pronounced against Realists (and Pragmatists, too), and most of the times without good reasons-. But even if the accusations of moral relativism were true - i.e. if all Realists were really absolutely indifferent to the ends legal systems should purse, which is not the case $\mathrm{e}^{15}$ - this does not mean that they did not have, or at least some of them had, clear normative ideas on how, and through what method, to achieve those ends, whatever they might be. This aspect of normativity could be dubbed "methodological" (or "formal") because it is not concerned with the ultimate ends of law or justice (i.e., what should be done) but rather just with the best method for achieving them (i.e., how it should be done). This methodological normativism is most evident when applied to adjudication and legal processes — which are, at their core, nothing but methods to take decisions-.

To clarify: rarely Realists have provided a sharp criterion according to which is possible to tell the difference between a "just" law and an "unjust" one, or between a "just" decision and an "unjust" one in a substantive sense. But many of them have had clear ideas on what a good method for deciding cases (i.e., adjudication) should look like and how it should be designed or arranged normatively -i.e., the "forms" of adjudication, in Lon Fuller's sense- ${ }^{16}$. For example, as we shall see, adjudication should allow a complete gathering of all the relevant information, and it should enable the judge to decide by relying on the totality

\footnotetext{
${ }^{13}$ See infra, paragraph 4.1 .

${ }^{14}$ On the methodological functionalism of Legal Realists, see the works of Cohen (1937; 1935; 1934), and Clark (1929).

${ }^{15}$ The fact that the ultimate goals of the legal system mattered for Legal Realists has been recently demonstrated —at least in tort law, and at least taking into account the writings of Oliver Wendell Holmes, Karl Llewellyn and Leon Green- by Ursin (2012a; 2012b).

16 "By forms of adjudication I refer to the ways in which adjudication may be organized and conducted" (Fuller, 1978, p. 354).
} 
of factual elements, it should emphasise his responsibility, and it should not unduly constrain him with unnecessary formalism, and so on. ${ }^{17}$

\section{Charles Edward Clark's "Procedural Philosophy"}

Among Realists, Charles Edward Clark (1889-1963) was undoubtedly a prominent "methodological normativist" or a "nonquietist", in Brian Leiter's words. Theoretically and practically he put forward an ambitious reformist agenda of civil justice, inspired by guidingideas characteristically belonging to Realism and to the pragmatic tradition. In addition, having served as Reporter for the Advisory Committee for the Reform of the Federal Rules of Civil Procedure (hereinafter, FRCP), he managed to translate his procedural philosophy into reality. In fact, not only he advised that reform, but he is widely, and rightly, considered as the main "inspirer" and the true "father" of it. ${ }^{18}$

Charles Edward Clark lived the legal experience in its entirety. He was attorney, distinguished scholar, and a member of the judiciary. He graduated in law from Yale College in 1913. After a brief period in private practice and as a Republican politician in Connecticut, he began his law career at Yale faculty in 1919, in a time in which Yale started to be a major hub for Legal Realism. At Yale, he went through the whole academic path, becoming first Sterling Professor of Law and then Dean of the Law School, from 1929 to 1939. In 1938 he also served as a Special Assistant Attorney General for the Antitrust Division in the U.S. Department of Justice. Eventually, in 1939 he was nominated Judge for the Second Circuit on the U.S. Court of Appeals until his death, in 1963. Although, lamentably, his name does not appear in most of today's discussions about Realism, he was recognized by his colleagues and other best-known exponents of the movement as a Realist, and himself self-identified as such.

Clark's Realism emerges with great evidence in his "procedural philosophy", or, as it has been called, in his "procedural jurisprudence" (Marcus, 2010, p. 451).

But what does it mean? Which is the distinctive feature all Realists must have to be legitimately called "Realists"? It is not only the faith in anti-formalism and anti-conceptualism but - more crucially - the entrenched faith in the power of facts to determine the content of a decision (and of a legal decision in particular). This is what Brian Leiter called the "Core Claim” of Legal Realism, namely that claim that is common to all Legal Realists, and despite their many differences: "in deciding cases, judges respond primarily to the stimulus of the facts" (i.e., "non-legal reasons"). Or, to put it more straightforward, all Realists agreed upon the statement that "judges reach decisions based on what they think would be fair on the facts of the case, rather than on the basis of the applicable rules of law" (Leiter, 2007b, pp. 21-22 ${ }^{19}$. With Realism, facts took centre-stage. Of course, by "facts" here is meant not only those made relevant by the applicable legal rules (otherwise the Core Claim would sound obvious and redundant), but - more comprehensively - all the underlying facts of the case, including the ones deemed relevant by the parties themselves or by the judge, the wider

\footnotetext{
${ }^{17}$ Brian Leiter has argued that many Realists were, from a normative viewpoint, "quietists" (such as Jerome Frank), while others (such as Karl Llewellyn) adopted a more subtle version of quietism that could be described as a "ratification of what happens". In his own words: "A more subtle version of quietism, however, is apparent in Llewellyn's work. Here the Realists are not entirely silent on normative questions; they simply give as explicit advice that judges ought to do what it is that they largely do anyway" (Leiter, 2005, p. 58). Compare also Leiter (1996, p. 277; 2007b, p. 63, footnote 18). As David Marcus put it, Realists often derived the "Ought" of the law from the "Is" of reality (see Marcus, 2010, p. 465-470).

${ }^{18}$ Acknowledging Clark as the most important figure in the drafting of the FRCP, see, e.g., Rodell (1965); Smith (1976); Subrin (1991).

${ }^{19}$ As Brian Leiter recalls, Karl Llewellyn speaks of the "fact-pressure of the case" (Llewellyn, 1931, p. 1234) or, differently stated, of "the sense of the situation as seen by the courts" (Llewellyn, 1960. p. 397).
} 
"social reality" as well as the expectations of the parties, especially when deciding commercial disputes (Leiter, 2007b, p. 22).

In Clark's view this descriptive claim becomes a normative command: judges should respond primarily to the stimulus of facts rather than formal rules, in order to achieve just results. Judges — in Clark's view — not only are not, but should neither be, primarily ruleresponsive, but primarily fact-responsive.

This broad ideology inspired the architecture of the FRCP and exemplifies perfectly how the underpinnings of ALR were translated into enduring legal reforms. A caveat, however, is needed. The following parts (3.1. and 3.2.) will not be concerned in detailing how and which of Clark's opinions have been translated technically into the FRCP. Rather, the goal is, less ambitiously, to delineate his leading ideas, so to say, in a functional way; his contributions that interests here most are those that express in a fashion consistent with ALR the features of rules, decision-making procedures, and justice that —as it will be suggested — inform also the current tendencies towards a "privatization of dispute resolution" that we are experiencing at a global level, rendering it a true "Realist project".

\subsection{Clark's Legal Realism as a Theory of Procedural Rules and Judicial Function}

In his writings, although in a fragmented way, Clark exposed a sort of "general theory of adjudication”. He formulated (a) a theory of procedural rules, (b) a theory of judicial function, and (c) a theory of legal decision. These three theories are closely-intertwined. It could be said that the first one (the theory of procedural rules) is derived from the second one (theory of judicial function), so it is appropriate to begin by delineating the latter.

By and large, Clark purported a "pragmatic method" of judicial decision-making, i.e. a method oriented to the consequences. One the one side, he expressed open recognition of judicial powers and their virtues. On the other side, he insisted in the necessity that the judge should be responsible — in his own's eyes, and in the eyes of the public - for the way in which he decides. Here, Clark's Realism is evident: it is never the law that decides the dispute, but the decision-maker. Salvatore Satta, the great Italian civil procedural law scholar of the last century, who could be labelled himself a Realist, so expressed this idea in his brief but dense book The Mystery of Process: "the reality is that the one who kills is not the law-maker, but the judge; it is not the law, but the judicial pronouncement" (Satta, 1949, p. $17)^{20}$. The judge should therefore enjoy a high degree of discretion but, being conscious of this, should also bear full responsibility - the two aspects being not separated-. Since the final decision realistically depends upon him, he should not hide himself behind the veil of a false formalism. ${ }^{21}$ In Clark's words: "Judges should solve legal problems with good results in particular cases as the goal [...] and the court bears ultimate responsibility for the outcomes" (Clark, 1925, p. 548).

A common metaphor used by Clark is that courts should be similar in their function to administrative agencies (Clark and Douglas, 1951, p. 767). Judges must enjoy the same ample discretion to solve legal problems as administrators, in a manner targeted to achieve good results in individual cases, and rules should not impede this task. "Courts procedures, to be workable, must be treated as a means to an end, not an end itself. Instead of being controlled by formidable rules [...] it should be operated flexibly by wise administrator exercising wide discretion" (Clark, 1934, p. 362) 22 .

\footnotetext{
${ }^{20}$ This is my translation.

${ }^{21}$ This is a common view among Legal Realists; see, e.g., Llewellyn (1962; 1942); Frank (1948); Cohen (1937).

${ }^{22}$ For a further specification of this idea, see also Clark (1961).
} 
The judge, in his capacity, would act less as an umpire and more as an administrator, creating a less adversarial climate in courts and even facilitating settlement, if he considers so appropriate. ${ }^{23}$ In this respect, Clark could be seen as an early, ante-litteram advocate of case-management, a major trend of today's administration of civil justice. ${ }^{24}$

The judge, not the rules, are to be the master of civil processes. The judge, so to say, is more like a director of an orchestra, who uses his "artistic" abilities in order to make the musicians play orderly together, than a passive executor of the will of the composer. As Clark put it, to skilfully direct, manage and "pilot" a case is "the perfection of the judicial art" (Clark, 1956, p. 165; reported also by Marcus, 2010, p. 499).

Clark's theory of procedural rules follows that of the judicial role just delineated. Accordingly, rules governing procedure should be crafted specifically to vest the decisionmaker with ample discretion. "Procedural rules must be viewed as grants or creations of judicial power" (Clark, 1949, p. 493). "Rules should force judges to rely on their own brain" (Marcus, 2010, p. 487).

What it's seen here is a striking similarity with pragmatist philosophical thought. Just like for Pragmatists, who considered particular social problems as the starting point of human enquiry and that, to be solved, they must stimulate the free thought from the data available, so for Realists specific legal problems are the starting points that urge decisionmakers (here, the judges) to think afresh and freely to appropriate legal solutions, relying upon they own knowledge.

Of course, Clark, as a proceduralist, could not think of simply getting rid of the rules of procedure. What is interesting, though, is how he conceived their relationship with the outcome of adjudication. As he evocatively said, the rules of procedure should be the "handmaid of justice". As a handmaid, their presence should never be so intense as to hinder the main job. The handmaid's task is to help and facilitate what is meant to be done, not to govern it. If this is not the case, the handmaid should be brought under control. Similarly it goes with rules: if their presence does more harm than good, then there is no choice but to "control" them (or change them). In his own words:

Although I agree [...] that a Court cannot conduct its business without a code of procedure, I think that the relation of rules of practice to the work of justice is intended to be that of a handmaid rather than mistress, and the Court ought not to be so far bound and tied by rules, which are after all only intended as general rules of procedure, as to be compelled to do what will cause injustice in the particular case [...]. A handmaid, no matter how devoted, seems never averse to becoming mistress of a household should the opportunity offer. Just so do rules of procedure tend to assume a too obtrusive place in the attention of judges and lawyers — unless, indeed, they are continually restricted to their proper and subordinate role- (Clark, 1938, p. 297).

This brief excerpt encapsulates Clark's theory of procedural rules and the spirit of his reform, characterized by the "due subordination of civil procedure to the end of substantive justice" (Clark, 1938, p. 297). The formal fairness of the procedure is not as important as the substantive outcomes it might generate. Rigid respect for procedural forms, regardless of their capacity to provide a "good" solution, is sheer non-sense. "The formal fairness of a procedure

\footnotetext{
${ }^{23}$ Although Clark said that settlement is "an important by product, though properly approached more as a desirable consequence than a compelled objective”, see Clark (1951) as reported by Marcus (2010, p. 499, footnote 385).

${ }^{24}$ Generally, on this phenomenon, Resnik (1982).
} 
(i.e., the fact that it faithfully followed a formally established process) meant nothing if the procedure did not facilitate the efficient and accurate resolution of controversies on their merits" (Clark, 1938, p. 297).

Of course, he accepted that the purpose of adjudication is to decide cases on their merits. But he did not conceive the merits of the case as its "substantive merits" formally conceived — namely, as the blind application of substantive law — but rather as a "substantively just" determination (Marcus, 2010, p. 492). What is worth noting is that Clark is always careful not to use the expression "substantive law". He prefers the far more general, but also far more nebulous, words of "substantive justice". For, as he refuses formalism in the conduct of litigation, he refuses formalism in the application of private law, too. If, according to the functionalist mantra of pragmatism, rules are means and not ends, the formal coherence of the decision with previously established standards is not a value per se. For him, the primary judicial function is —as he put it_ "giving justice between man and man" (Marcus, 2010, p. 492), which is a different task from "applying the law".

But what does it mean "substantive justice"? Can we make sense of what a "just solution" denotes for Realists?

\subsection{Clark's Legal Realism as a Theory of Judicial Decision}

This last question can be answered to in a pretty straightforward manner. A just solution (i.e., a solution that could be labelled as "substantively just") is for Clark and for Realists more generally the one that generates the best consequences, and not the one that interprets or applies a norm more correctly than another. And, it is evident, to reach this consequenceoriented result, decisions need to be taken "all things considered".

It has been seen that, for Realists, judges respond primarily to facts and that, for Clark, judges should respond primarily to facts, whereas "facts" are understood in a very comprehensive fashion, including social factors and social realities as they emerge from the narrative of the parties. Clark emphasized the importance of "telling the whole story" in the proceeding. This fact-centred approach can be illustrated with an example. Clark spent a lot of efforts in criticizing the common law pleading (a moment of the civil procedure of his times) that was still characterized by an incredible formalism, the use of the forms of action and the formation of a single issue of law to be decided (Clark, 1925; Clark, 1924a). He thought, by contrast, that the parties should be allowed to present all the factual material they deemed relevant, without formalism and conceptualism. He thus advanced the introduction of the Rule 8 of the FRCP, which, still today, reads that the plaintiff, in order to initiate a suit, must just allege a "short and plain statement of the claim showing that the pleader is entitled to relief". What it's possible to see here is that, in this formulation, the previous, conceptual distinction between "statements of facts" and "statements of law" - which gave rise to infinite disputes - is absent, and so is the term "form of action", which was present in the early formulation (Marcus, 2010, p. 493497; Clark, 1924b). ${ }^{25}$ Clark wanted the party to describe freely and simply the series of event as they occurred, so that the outcome could "mirror" the whole factual reality in its uniqueness. "Every judge worth his salt will try his best to individualize each case before him so as to reach a just result to the individuals without regard to generalities" (Clark, 1963, p. 2).

${ }^{25}$ See also, analyzing Clark's conception, Sherwin (2008). 
A broader distrust for what is general, universal, and an appreciation for what is particular, specific, underpins this view. This is a common concern for Realists: Jerome Frank, for example, in his "Law and the Modern Mind" argued that generalizations lead to a "de-humanized" form of justice and called for a process of "individualization" of law (Frank, 1930, p. 191). For Realists, law generally, and legal decisions specifically, should be intended as the pragmatic response to immediate problems and questions, that differ from time to time, from context to context, from people to people ${ }^{26}$. Law becomes necessarily fragmented, a constant process of working and re-working. Law, in their view, is dynamic, not rigid; it is action, not a stasis. As Clark said, there is "nothing [...] more fluid and mobile than the law" (Marcus, 2010, p. 466). Law, to paraphrase Karl Llewelyn, is not a "Given", but a "Doing" ("Before rules, were facts; in the beginning was not a Word, but a Doing", as he wrote, 1931, p. 1222). Law, to quote Oliver Wendell Holmes Jr., is “Experience”, not "Logic” (Holmes Jr., 1881, p. 1).

It should be stressed, however, that the kind of judge delineated by Clark, although enjoying a significant amount of discretion and being responsible for it, does not act arbitrarily. His discretion is not unfettered. To understand this very point, we should remember the role of facts in both for Pragmatists and for Realists. For them, facts (i.e. empirical data, or knowledge) and an a-dogmatic use of human intelligence is all we need to solve problems. A theory of ultimate ends is not needed.

In law —as Clark will say_ "facts speak for themselves" (Marcus, 2010, p. 503) ${ }^{27}$. And we have seen that by "facts" Clark and the Realists included also the wider "social realities" parties belong to as well as the "social environments" in which the dispute took place. So, the judge should "match" as much as possible the social conventions that form part of the parties' context, so as to avoid "disconnect grow between how a judge solved a legal problem and how affected laymen might expect it to be solved” (Marcus, 2010, p. 468). This is, by the way, also the "jurisprudence" underlying the Uniform Commercial Code, that advised judges to decide cases according to "commercial practices and customary standards of fair dealing", in an attempt to harmonize legal decisions with merchant customs and usage (Marcus, 2010, p. 469). In Realists' view, law and the outcomes of legal decisions emerge almost spontaneously from facts. Therefore, a "fact-driven" process, along with the wise and free exercise of judicial discretion, cannot but lead to a just decision. If facts are accurately gathered and presented and if the judge focuses on the immediate problem at stake, the answer will almost automatically stem.

For this reason, Clark did not feel the need to delineate a theory of substantial justice, a theory of "ultimate ends". Justice cannot be but individualized, context-depend.

The similarity between the pragmatic concept of truth and the Realist concept of justice cannot be more evident. As for Pragmatists different contexts and environments must lead to different solutions, so for Realists different fact-situations must lead to different outcomes and require thus different "justices". If for Pragmatists truth was nothing more than the resolution of a problem ${ }^{28}$, the same could be said of justice for Realists (and for Clark surely): justice is nothing more than the resolution of a (legal) problem. Justice, like truth, is never universal, eternal, but always particular and holds only for the present.

\footnotetext{
${ }^{26}$ E.g., for Max Radin, another prominent figure in the realist movement, this meant that judges needed to "keep themselves aware that they are required to base their judgments on unique events in which non-interchangeable individual human beings are concerned"; see Radin (1931).

${ }^{27}$ Marcus (2010, p. 509) also correctly defines this view as "naive": "Jurisprudential opponents recognized the obvious flaw in realist reforms: facts do not speak for themselves but require a prism of substantive value to acquire meaning".

${ }^{28}$ See supra, paragraph 2.
} 


\section{The "Privatisation of Dispute Resolution" as an "Un-intended Realist Project"}

How did Realists contribute to shape contemporary legal practices? What is, by and large, their legacy nowadays?

These questions could be answered by illustrating one of the most significant transformations (philosophically, politically, ideologically) that has occurred in the field of dispute resolution over the past decades, namely the privatisation of civil justice.

Over the past twenty years, at a global level, countless reforms, initiatives, and projects sought to encourage, if not force, the resolution of private disputes through alternative, settlement-oriented mechanisms (such as mediation, conciliation, and various forms of negotiations ${ }^{29}$ ) while at the same time discouraging people from going to court. As a consequence, in practically every jurisdiction of the world, the vast majority of private controversies are resolved privately prior to the judgment, or even prior to going to court, and only a small percentage of cases terminate with a judicial determination. This tendency has affected especially the two major common law countries: Professor Marc Galanter, in the United States, calls it the "vanishing" of civil trials (Galanter, 2005; 2004) ${ }^{30}$, while Professor Dame Hazel Genn, in England and Wales, calls it a "privatisation of civil justice" (Genn, 2013; 2009, pp. 65-69). These two expressions capture two different faces of the same phenomenon: the disappearance of trials in court ("the vanishing of civil trials") caused by the concomitant outsourcing of dispute resolution to private decision-makers or, more rightly, to settlementfacilitators ("the privatisation of justice"). This transformation, however, is in no way confined to these two jurisdictions: similar trends also exist in other common law countries since long (such as Canada $^{31}$, Australia ${ }^{32}$, Singapore ${ }^{33}$ ), and favouring extra-judicial means of dispute resolution is now a priority of current civil justice policies at European level and domestically in continental legal systems, too. ${ }^{34}$

This part is not concerned in detailing technically how this global wave of reforms has been implemented in the various legal systems of the world. Suffice it to note that, at a regulatory level, some jurisdictions have moved towards a system inspired to the technique of "nudges", i.e. aiming to encourage early-stage or court-connected mediation and the settlement of the dispute by imposing potential monetary penalties at trial, in case of unreasonable conduct, upon the loosing (or, in some cases, even upon the winning) party, but without formally questioning the dogma of the voluntariness of $\mathrm{ADR}^{35}$; other jurisdictions, on the contrary, have opted to render mediation explicitly mandatory before trial for certain matters, but not for others. ${ }^{36}$

What this part focuses on is, rather, the "ideological tools" employed by ADR advocates, broadly speaking - i.e., what purposes they set, what advantages they emphasize, and what promises they make-.

\footnotetext{
${ }^{29}$ This essay is not concerned with arbitration because —although an important ADR mechanism — it is not, normally, settlement-oriented. For the emphasis of the different "moralities" between arbitration and other ADR services in this sense, see Fuller (1962, p. 29).

${ }^{30}$ Further explanations on this trend in Resnik (2014) and Langbein (2012).

${ }^{31}$ See Farrow (2014).

${ }^{32}$ See, critically, Noone (2011).

${ }^{33}$ See Ahmed and Quek Anderson (2019), assessing comparatively courts' encouragement of ADR between England and Wales and Singapore.

${ }^{34}$ For example, the Directive 2013/11/UE (on ADR for consumer disputes), the Regulation 2013/524/UE (on Online Dispute Resolution for consumer disputes) and the early Directive 2008/52/CE/ (on mediation, and that applies to crossborder disputes in civil and commercial matters) all go in this direction.

${ }^{35}$ This is the technique adopted in the English legal system; see Ahmed (2012).

${ }^{36}$ This is the technique adopted, e.g., in Italy. For a general account, in English, see Nolan-Haley (2012).
} 
By considering these, it is argued that the privatization of civil justice is better understood as a legal Realist "un-intended" project ${ }^{37}$. It is said "un-intended" because Realists did not particularly encouraged settlement as a means to solve private controversies, nor they explicitly engaged themselves in sponsoring alternative dispute procedures, nor they envisaged the end of a system of public court adjudication. It is simply suggested that the ADR revolution is "realistic" in the sense that not only it shares, but takes to the extremes, too, some of the key ideas that form the basis of the Realist view about the solving of private controversies and about legal rules more generally. Indeed, anti-formalism, anti-conceptualism, a problem-solving attitude, a de-emphasis on the role of law in determining the final outcome of decisions, the importance of considering the whole factual background (including the expectations of the parties at dispute), an insistence on the need to "go beyond" what legal rules say in order to achieve a better form of justice and so on, are all principles of ALR that apply and fit perfectly to the ADR legal thought ${ }^{38}$.

Therefore, the privatisation of civil justice could be better understood as an unintended consequence, or by-product, of the realist view of law. The privatisation of dispute resolution is a "Realist project" without knowing being one.

\subsection{Alternative Dispute Resolution: Anti-Formalism Vs In-Formalism, Contextualism, Particularism}

Generally, the ADR legal thought — whether one agrees with it or not - has profound, farreaching philosophical dimensions that are rarely considered and fleshed out. It conveys precise normative ideas on how conflicts should be best solved and what "doing justice" means, and it communicates them in an appealing way.

What lies at the core of its message? What is so appealing about it? Let us put apart budgetary and efficiency considerations (such as the fact that ADR services are cheaper and faster than court adjudication) that are not philosophically significant, at least for the purposes of the arguments here deployed, and let us concentrate on the values and ideals ADR promote.

To this extent, three themes will be isolated, that seem recurring most both in the Realist view of adjudication and in the ADR legal thought (and in the Pragmatic philosophical tradition, too). The first one is the solving-problem approach and, therefore, the refusal of formalism in the conduct of the process; the second one is the emphasis of the role of facts in determining the solution of the case, and the third one is the concept of "individualized" justice.

(1) The first theme is the conception of the process of dispute resolution as a "problemsolving" mechanism (Menkel-Meadow, 1984). Of course, the logic of "problem-solving" is

\footnotetext{
${ }^{37}$ There is another sense in which the ADR can be understood as an institutional consequence or a "by-product" of Realist thought, and in particular of the Realist basis of the reform of the FRCP. This lies in the fact that the movement toward the privatization of civil justice that the United States has experienced is due, at least in part, to the enormous costs of going to court. The FRCP have designed such a complex and powerful machinery, equipped with instruments and mechanisms in order to achieve the best results, that has revealed itself simply too costly to afford. In this light are to be seen the efforts, put forward by the entire oeuvre of Mauro Cappelletti, aimed at enhancing access to justice by improving ADR (the so-called "third wave" of the Access to Justice movement). For all these reasons, see Cappelletti (1993).

${ }^{38}$ This link has been rarely done explicitly. There are, however, two notable exceptions. One is represented by Carrie MenkelMeadow, one of the leading experts and advocates of ADR mechanisms. In a much-cited article of her (1995, p. 2677) she writes: "I have often thought of interest-based negotiation and mediation as a legacy of legal realism. They are adaptive expressions of the interaction of the "law on the books" with the needs and interests of real people"; and in another essay (2004, p. 12): the "focus on "disputing process" de-centers — but does not eliminate — law as the primary variable explaining how disputes are resolved [...] was a natural derivative of the school of legal realism". The other exception is represented by an article of Robert Rubinson (2017) who explicitly examines the connections between Realist legal thought and the practice of mediation (also quoting and building upon the work of Northrop (1958).
} 
framed and conceptualized differently in the Realist and in the ADR paradigms. Most obviously, in the first one is the judge that is the one called to solve authoritatively the dispute, while in the latter are the parties that are meant to be the "solvers" of their own issues. Also, while ADR services intuitively require the cooperation and negotiation between the parties, this element is generally extraneous to the Realist conception of adjudication ${ }^{39}$. However, despite their differences, both these approaches share, at their core, the same ideology - that is conceiving a dispute as a problem to be solved-. The words here are important. Thinking of a dispute as a problem, indeed, means per se conceiving the final outcome of the procedure - be it a binding judgment or a settlement - as the solution of that very problem. And solutions, by definition, are assessed only on the ground of their capacity to be effective, responsive, satisfactory, adequate, not for being "formal" or "coherent" or "consistent with previous determinations" or "fixed". A solution that is taken just for being "formally mandatory", or because it automatically and mechanically proceeds from general principles or long-held traditions, and regardless of its actual "solving potential", is not a solution at all, in the strictest sense of the word.

This means that both paradigms - i.e., the Realist view of adjudication and the ADR logic - agree upon the point that formalism is to be rejected. Does this decision represent a good solution to the legal problem that has been posed? Does it solve the issue at stake, in a satisfying manner, in the real world? are, normally, questions that a judge does not ask himself, nor he is supposed to, within the formalist framework of law, where all that matters is whether the legal judgment is logically and deductively a consequence from the law or not ${ }^{40}$.

Of course, it should be made clear that formalism is rejected both in the conduct of the process (i.e., procedurally) and in the content of the final outcome (i.e. substantially).

Procedurally speaking, for Realists, the rules that govern the process are seen as something that, although necessary, should not interfere with the task of doing justice.

This is their "anti-formalism". The ADR thinking takes to the extreme this view; procedural rules are not simply "tolerated" as long as they do not hinder the task of doing justice, but they are not "tolerated" at all. In the ADR view, forms are considered per se as something that render more difficult doing justice, while the absence of any formalities is deemed inherently superior ("in-formalism"). Therefore, ADR are not "anti-formal" means of solving disputes, but — more radically — "in-formal" ones. ${ }^{41}$ Indeed, in ADR services, parties can normally choose how to organize their own interactions, decide what to discuss in them, and in what way to do it. By refusing adversarial litigation and favouring informal discussion and free conversation — so goes the thought - they promote autonomy and self-empowerment and are, as such, capable to eventually provide a better, "warmer" kind of justice (Smith, 1978), in a way that better suits our postmodern world (Menkel-Meadow, 1996) ${ }^{42}$. Of course, this is quite a radical interpretation of the phenomenon. Concretely today's ADR practices are moving towards a hybridization, where different forms of in-formal, semi-formal means and even adjudication coexist together (think about services such as "med-arb", "early neutral evaluations", "summary

\footnotetext{
${ }^{39}$ Although Clark himself proposed that the judge, using his powers of case management, can invite parties to settle the case, see supra, paragraph 3.1., text and footnote 24.

${ }^{40} \mathrm{Of}$ course, this is an oversimplification of a complex ideology; see, for a more balanced and positive account, see Schauer (1988); Leiter (2010).

${ }^{41}$ The debate over the function of "forms" in dispute resolution is a complex one and cannot be tackled adequately here; for example, for an argument that "forms" are fundamental in protecting minorities and weak parties against prejudice, see Delgado, Dunn et al., (1985) and more recently Delgado (2017).

${ }^{42}$ It is worth stressing that in this scholarship (that could be dubbed "postmodern") trial is understood traditionally (i.e. in a non-Realistic fashion), and this is the reason why ADR scholars strongly oppose to it.
} 
jury trial", "mini trials", and the like, each of which enjoys a different degree of formality ${ }^{43}$ ). But, in essence, in its purest version, the ADR view sees any kinds of formality suspiciously.

(2) In ADR thinking formalism — as it has been said before- is rejected also from a substantial viewpoint. For ADR supporters, parties should be as much free as possible to construct the content of the settlement regardless of what the rules of the law might say over specific points ${ }^{44}$. When Lon Fuller, describing the process of mediation, pointed out that its specific morality lies in the fact that it "liberates parties from the encumbrance of rules [...] without the aid of formal prescriptions laid down in advance" (Fuller, 1971, pp. 325-326), he expresses an exigence that it is shared with Realists. Just like for Realists (and Pragmatists in philosophy as well) facts, not rules, should be the only guiding-factors in solving controversies. But here, too, the ADR view takes one step further Realists' de-emphasis of formal legal rules in determining the decision. For ADR supporters, the whole context in which the dispute arose is to be taken into account, including disputants themselves understood in their capacity as concrete individuals, with their personal histories, experiences, desires, preferences, aspirations, needs, exigencies, material resources, conditions, possibilities, and the like. Anything could, and should, be discussed. Emotions too are considered "facts" for the purposes of the solution of the conflict (Shapiro, 2002). This is crucial, for example, when it comes to the so-called "transformative mediation" — namely that kind of mediation that, in its most ambitious version, aims to transform "existentially" the parties and to make them shift towards each other (Baruch and Folger, 1994) —. As Robert Baruch Bush and Joseph Folger - two leading American experts in this field- noted: "there are facts in feelings" (1996, pp. 271-272).

(3) Such an intense emphasis upon the broad context of the dispute and on the specific environment in which the dispute arose inevitably leads to see and treat every conflict as unique. The more facts enter the process, the less we will be inclined to consider the controversy at stake as belonging to a wider class. Similarity, after all, is just a matter of simplifying complexity and the variety of experiences. In traditional, formal legal thought, controversies are always seen as a part of a larger group, namely as instances of a general scheme which is defined by a common factual element. That is how law operates. Lawmakers, in drafting legal norms, necessarily take into consideration some facts and leave out others. As Hans Kelsen famously put it: "to legislate means to generalize" ("Gesetzgeben heißt verallgemeinern”, Kelsen, 1925, p. 232). As such, justice, understood in its formal sense, requires that every controversy included in the same category be solved through the same solution, which is provided by the law once for $\mathrm{all}^{45}$.

Realists and to an even major degree ADR theorists embrace a radically different view. In the ADR thought, two cases alike simply do not exist; and as long as cases are always different, so have to be the remedies, too. These need to be individualized, particularized, imaginative, creative; they should be able to provide different things from what the justice system typically provides — for example, non-monetary remedies, such as apologies_-. ${ }^{46}$ There is not a "one-size-fit-all" solution. Justice, in the ADR perspective (and in Realist legal thinking, as we have seen) is not a universal concept, but it is mostly defined by

\footnotetext{
${ }^{43}$ See, for a thorough description of those mechanisms, Menkel-Meadow (2013).

${ }^{44}$ In this sense, ADR procedures are alternative not only to adjudication, but to law more generally; see, for this intuition, Calvo Soler and Ferrer Beltrán (2007).

${ }^{45}$ This feature is called "Law's abstract judgment" and it has been recently investigated from a philosophical viewpoint by Lucy (2017).

${ }^{46}$ See, e.g., Pavlick (2003).
} 
those who are directly engaged in it. For ADR scholars, justice, by definition, cannot be but particular; a "general justice" is an oxymoron. Justice, like truth for pragmatism, is a question of "fitness" 47 .

However, the consequences of characterizing every dispute as unique, and thus every just solution as necessarily tailor-made, should not be taken lightly. If every controversy, and therefore every solution, is different from one another, then nothing is foreseeable. If neither controversies nor the ways in which they are solved follow certain predictable patterns, then the legal world is just composed of a plethora of determinations we could not make sense of. This means that in the ADR legal though the need for legal certainty, understood as the exigence to be able to predict how possible disputes might end, ceases (normatively) to be a value worth pursuing.

\section{Conclusion}

What this article has sought to unveil is a sort of "line of continuity" between classic Pragmatism, Legal Realist thought, and the current practice of Alternative Dispute Resolution as a way to end disputes. Basically, those are all ideologies (or mentalities) that reject formalism and universalism and embrace a process of "individualization" ("particularization"), either of truth or justice.

Now that the ADR message has a global reach and its "rhetorical force" is so pervasive, the transformation it purports in our way to look at law deserves careful attention. Forty years ago, the great English jurist Patrick Atiyah observed an existing tendency in the common law world that he dubbed "from principles to pragmatism" (Atiyah, 1980; 1987). That trend was marked by a preference for the concrete over the abstract, the pragmatic over the theoretic, the exception over the general, and more generally by a form of legislating that created on purpose greater spaces for judicial discretion. The motive underpinning that shift was the desire to achieve, in a pragmatic way, particular justice in specific cases before the courts. He also lamented that the implicit philosophical assumption was that "justice can only be done by the individualized, ad hoc approach, by examining the facts of the particular case in great detail and determining what appears to be fair, having regard to what has happened" (Atiyah, 1980, p. 1259).

What Professor Atiyah was detecting was a transformation occurring within the (English) judiciary and legislation, but it is exactly what is conveyed now, by and large, by the ADR revolution at a global level. Highlighting these pragmatic and Realist roots of all ADR mechanisms, and of mediation in particular, will help to see more clearly through the not-so-transparent waters of the privatization of dispute resolution, assess its strength and weaknesses as well as its advantages and risks.

\section{Bibliographical references}

Ahmed, M. and Quek Anderson, D. (2019). Expanding the Scope of Dispute Resolution and Access to Justice. Civil Justice Quarterly, 38 (1), 1-8.

- (2012). Implied Compulsory Mediation. Civil Justice Quarterly 31, 151-175.

Alberstein, M. (2002). Pragmatism and the Law: From Philosophy to Dispute Resolution, London: Ashgate.

${ }^{47}$ Supra, paragraph 2. 
Atiya, P. (1987). Pragmatism and Theory in English Law. The Hamlyn Lecture. London Stevens and Sons.

- (1980). From Principles to Pragmatism. Changes in the Function of the Judicial Process and the Law. Iowa Law Review 65, 1249-1272.

Baruch Bush, R. A. and Folger, J. P. (1996). Transformative Mediation and Third-party Intervention: Ten Hallmarks of a Transformative Approach to Practice. Mediation Quarterly 13 (4), 263-278.

- (1994). The Promise of Mediation. The Transformative Approach to Conflict. San Francisco: Jossey-Bass Publishers.

Bell, D. (1992). Racial Realism. Connecticut Law Review 24, 363-379.

Bix, B. B. (2008). Legal Philosophy in America. In: Misak, C. (ed) The Oxford Handbook of American Philosophy. Oxford: Oxford University Press.

Calvo Soler, R. and Ferrer Beltrán, J. (2007). Gli ADR nel diritto: uno sguardo giusfilosofico. In Varano, V. (ed), L'altra giustizia. I metodi alternativi di soluzione delle controversie nel diritto comparato. Milano: Giuffrè.

Cappelletti, M. (1993). Alternative Dispute Resolution Processes within the Framework of the World-Wide Access-to-Justice Movement. The Modern Law Review 56 (3), 282296.

Capps, J. (2019). The Pragmatic Theory of Truth. In: Zalta E. N. (ed) The Stanford Encyclopedia of Philosophy. https://plato.stanford.edu/entries/truth-pragmatic/.

Clark, C. E. (1963). The Limits of Judicial Objectivity. The American University Law Review 2, 1-13.

- (1956). Objectives of Pre-Trial Procedures. Ohio State Law Journal 17, 163-170.

- (1951). Book Review (reviewing Nims, H. D., Pre-Trial, 1950). 51 Columbia Law Review 25, 69-78.

- (1949). Special Problems in Drafting and Interpreting Procedural Codes and Rules. Vanderbilt Law Review 3, 493-508.

- (1938). The Handmaid of Justice. Washington University Law Quarterly 23(3), 297-320.

- (1934). The Cause of Action. University of Pennsylvania Law Review 82, 354-362.

- (1929). Methods of Legal Reform. West Virginia Law Quarterly 36, 106-118.

- (1925). History, Systems and Functions of Pleading. Virginia Law Review 11, 517-552.

- (1924a). The Real Party in Interest. Yale Law Journal 34, 259-276.

- (1924b). The Code Cause of Action. Yale Law Journal 33, 817-837.

Clark and Trubeck, D. M. (1961). The Creative Role of Judge: Restraint and Freedom in Common Law Tradition, Yale Law Journal 71, 255-276.

Clark and Douglas, W. O. (1951). Law and Legal Institutions. In Cohen, M. R., Cohen F.

S. (eds.) Readings in Jurisprudence and Legal Philosophy. New York: Beard Books.

Cohen, F. (1937). The Problem of a Functional Jurisprudence. Modern Law Review, q.

- (1935). Trascendental Nonsense and the Functional Approach. Columbia Law Review 35, 809-849.

- (1934). Modern Ethics and the Law. Brooklyn Law Review 4, 33-50.

Curtis, M. J. (2015). Realism Revisited: Reaffirming the Centrality of the New Deal in Realist Jurisprudence. Yale Journal Law and Humanities 27, 157-200.

Danzig, R. (1975). A Comment on the Jurisprudence of the UCC. Stanford Law Review 27, 621-535.

Delgado, R. (2017). The Unbearable Lightness of Alternative Dispute Resolution: Critical Thoughts on Fairness and Formality. SMU Law Review 70, 611-638. 
Delgado and Dunn C., et al. (1985). Fairness and Formality: Minimizing the Risk of Prejudice in Alternative Dispute Resolution. Wisconsin Law Review 6, 1359-1404.

Duxbury, N. (1995). Patterns of American Jurisprudence. Oxford: Oxford University Press.

Farrow, T. C. W. (2014). Civil Justice, Privatisation, and Democracy. Toronto: Toronto University Press.

Frank, J. (1930). Law and the Modern Mind. New York: Anchor Books.

- (1948). Say it With Music. Harvard Law Review 61, 921-957.

Fuller, L. L. (1978). The Forms and Limits of Adjudication. Harvard Law Review 92 (2), 353-409.

- (1971). Mediation. Its Forms and Functions. California Law Review 44, 305-339.

- (1962). Collective Bargaining and the Arbitrator. In Kahn M. L. (ed.) Collective Bargaining and the Arbitrator's Role, New York: BNA Incorporated.

- (1948). What the Law Schools Can Contribute to the Making of Lawyers. Journal Law Education 1 (2), 189-204.

Galanter, M. (2005). The Hundred-Year Decline of Trials and the Thirty Years War. Stanford Law Review 57, 1255-1274.

- (2004). The Vanishing Trial: An Examination of Trials and Related Matters in Federal and State Courts. Journal of Empirical Legal Studies, 459-470.

Genn, H. (2009). Judging Civil Justice. Cambridge: Cambridge University Press.

- (2013). What Is Civil Justice For? Reform, ADR, and Access to Justice. Yale Journal Law and the Humanities 24, 397-417.

Gilmore, G. (1961). Legal Realism: Its Cause and Cure. 70 Yale Law Journal, 1037-1048.

Glennon, P. (1985). The Iconoclast as Reformer: Jerome Frank's Impact on American Law. New York: Cornell University Press.

Haack, S. (2018). The Pragmatist Tradition: Lessons for Legal Theorists. Washington University Law Review 95, 1049-1082.

— (2005). On Legal Pragmatism: Where Does the "Path of the Law" Lead Us? 50 American Journal of Jurisprudence, 71-105.

- (1976). The Pragmatist Theory of Truth. 27, The British Journal for the Philosophy of Science, 231.249.

Holmes, O. W. Jr. (1881). The Common Law, 1881.

James, W. (1907). Pragmatism. In Pragmatism: A New Name for Some Old Ways of Thinking. New York: Longmans, Green and Co.

Kalman, L. (1997). Eating Spaghetti with a Spoon. Stanford Law Review 49, 1547-1581.

- (1986). Legal Realism at Yale: 1927-1960. Charleston: University North Carolina Press.

Kamp, A. R. (1995). Between-the-Wars Social Thought: Karl Llewellyn, Legal Realism, and the UCC in Context. Albany Law Review 59, 327-367.

Kelsen, H. (1925). Allgemeine Staatslehre. Berlin: J. Springer.

Langbein, J. (2012). The Disappearance of Civil Trial in the United States. Yale Law Journal $122,522-573$.

Legg, C. and Hookway, C. (2019). Pragmatism. In Zalta E. N. (ed) The Stanford Encyclopedia of Philosophy https://plato.stanford.edu/entries/pragmatism/\#PragTheoTrut

Leiter, B. (2015). Legal Realism and Legal Doctrine. 163, University of Pennsylvania Law Review 1975-1984.

- (2010). Legal Formalism and Legal Realism: What is the Issue? 16 Legal Theory, 112-143. 
- (2007a). Legal Realism and Legal Positivism Reconsidered. In Leiter B. (ed). Naturalizing Jurisprudence: Essays on American Legal Realism and Naturalism in Legal Philosophy. Oxford: Oxford University Press.

- (2007b). Rethinking Legal Realism: Toward a Naturalized Jurisprudence. In Leiter B. (eds.), Naturalizing Jurisprudence Essays on American Legal Realism and Naturalism in Legal Philosophy. Oxford: Oxford University Press.

- (2005) American Legal Realism. In: Golding M.P., Edmundson W. A. (eds.), The Blackwell Guide to the Philosophy of Law And Legal Theory. London: Blackwell.

- (1996). Legal Realism. In Patterson D. M. (ed.), A Companion to Philosophy of Law and Legal Theory. London: Wiley-Blackwell.

Llewellyn, K. (1962). Jurisprudence: Realism in Theory and Practice. Chicago: The University of Chicago Press.

- (1960). The Common Law Tradition. Deciding Appeals. Boston: Little Brown.

- (1942) On the Good, the True, the Beautiful, in Law. University of Chicago Law Review 9, 205-212.

- (1934) On Philosophy in American Law. 82 University Pennsylvania Law Review,

- (1931) Some Realism About Realism. Responding to Dean Pound. Harvard Law Review, 1222-1264.

Lucy, W. (2017). Law's Judgment. Oxford: Hart Publishing.

Maggs G. E. (2000). Karl Llewellyn's Fading Imprint on the Jurisprudence of the Uniform Commercial Code. University of Colorado Law Review 71, 541-572.

Marcus, D. (2010). The Federal Rules of Civil Procedure and Legal Realism as a Jurisprudence of Law Reform. 44 Georgia Law Review, 433-510.

Menkel-Meadow, C. (2013). Regulation of Dispute Resolution in the United States of America: From the Formal to the Informal to the "Semi-formal". In: Steffek, F. and Unberath, H. et al. (eds.), Regulating Dispute Resolution: ADR and Access to Justice at the Crossroads. Oxford: Hart Publisher.

- (2004). From Legal Disputes to Conflict Resolution and Human Problem Solving: Legal Dispute Resolution in a Multidisciplinary Context. Journal of Legal Education 54, 4-29.

- (1996). The Trouble with the Adversary System in a Postmodern, Multicultural World. William and Mary Law Review 38, 5-44.

- (1995). Whose Dispute Is It Anyway? A Philosophical and Democratic Defense of Settlement (In Some Cases). Georgetown Law Journal 83, 2633-2696.

- (1984). Toward Another View of Legal Negotiation: The Structure of Problem Solving. University College Los Angeles Law Review 31, 754.

Mensch, E. (2010). The History of Mainstream Legal Thought. In Kairys D. (ed.) The Politics of Law. A Progressive Critique. New York: Basic Books.

Milesm, T. J. and Sunstein, C. R. (2008). The New Legal Realism 75. University of Chicago Law Review, 831-851.

Mitchell D. T. (2007). Architect of Justice: Felix S. Cohen and the Founding of American Legal Pluralism. New York: Cornell University Press.

Nolan and Haley J. (2012). Is Europe Headed down the Primrose Path with Mandatory Mediation? North Carolina Journal of Int'l Law and Commercial Regulation 37, 9811011.

Noone, M. A. (2011). ADR, Public Interest and Access to Justice: The Need for Vigilance. Monash University Law Review 37, 57-80. 
Northrop, F. S. C. (1958). The Mediational Approval Theory of Law in American Legal Realism. Virginia Law Review 44, 347-364.

Pavlick, D. L. (2003). Apology and Mediation: The Horse and Carriage of the Twenty-First Century. Ohio State Journal of Dispute Resolution 18, 829-866.

Posner, R. (2003). Law, Pragmatism, and Democracy. Cambridge: Harvard University Press.

Radin, M. (1931). Legal Realism. Columbia Law Review 31, 824-828.

Resnik, J. (2014). The Privatization of Process: Requiem for and Celebration of the Federal Rules of Civil Procedure at 75. University of Pennsylvania Law Review 162, 1793-1838.

- (1982). Managerial Judges, Harvard Law Review 96, 374-446.

Rodell, F. (1965). For Charles E. Clark: A Brief and Belated but Fond Farewell. 65 Columbia Law Review, 1323-1030.

Rorty, R. (1990). Pragmatism, Davidson and Truth. In Objectivity, Relativism, and Truth: Philosophical Papers. Cambridge: Cambridge University Press.

Rubinson, R. (2017). Realizing Dispute Resolution: Meeting the Challenges of Legal Realism Through Mediation. Nevada Law Journal 18, 2-32.

Satta, S. (1940, reprint. 1994). Il mistero del processo, Milano: Adelphi.

Schauer, F. (1988). Formalism. Yale Law Journal 97, 509-548.

Shapiro, D. L., (2002). Negotiating Emotions. Conflict Resolution Quarterly 20, 67-82.

Sherwin, E. (2008). The Jurisprudence of Pleading: Rights, Rules, and Conley vs. Gibson. Howard Law Journal 52, 80-98.

Smith, D. (1978). A Warmer Way of Disputing: Mediation and Conciliation. American Journal of Comparative Law 26, 205-216.

Smith, M. E. (1976). Judge Charles E. Clark and the Federal Rules of Civil Procedure. 85 Yale Law Journal, 914-955.

Subrin, S. N. (1991). Charles E. Clark and His Procedural Outlook: The Disciplined Champion of Undisciplined Rules. In Petruck P. (ed.), Judge Charles Edward Clark. New York: Oceana Publications.

Summers, R. P., (1981). Pragmatic Instrumentalism in Twentieth Century American Legal Thought. A Synthesis and Critique of Our Dominant General Theory About Law and Its Use. Cornell Law Review 66, 861-948.

Tushnet, M. (1991). Critical Legal Studies: A Political History. Yale Law Journal 100, 15151544.

Ursin, E. (2012a). Clarifying the Normative Dimension of Legal Realism: The Example of Holmes's The Path of the Law. San Diego Law Review 49, 487-500.

- (2012b). The Missing Normative Dimension in Brian Leiter's "Reconstructed" Legal Realism. San Diego Law Review 49, 2-36. 